\title{
Lactobacillus acidipiscis sp. nov. and Weissella thailandensis sp. nov., isolated from fermented fish in Thailand
}

\author{
Somboon Tanasupawat, ${ }^{1}$ Osamu Shida, ${ }^{2}$ Sanae Okada ${ }^{3}$ \\ and Kazuo Komagata ${ }^{4}$
}

\footnotetext{
1 Department of Microbiology, Faculty of Pharmaceutical Sciences, Chulalongkorn University, Bangkok 10330, Thailand

2 Research and Development Department, Higeta Shoyu Co., Ltd, Choshi, Chiba 288-8680, Japan

3,4 Culture Collection Centre 3 and Department of Applied Biology and Chemistry4, Tokyo University of Agriculture, 1-1-1 Sakuragaoka, Setagaya-ku, Tokyo 156-8502, Japan
}

Author for correspondence: Somboon Tanasupawat. Tel: +662 2188376. Fax: +6622545195. e-mail: tsomboon@ chula.ac.th

Eleven strains of homofermentative, rod-shaped lactic acid bacteria and five strains of heterofermentative, sphere-shaped lactic acid bacteria were isolated from fermented fish (pla-ra and pla-chom) in Thailand. They were identified as new species and named Lactobacillus acidipiscis sp. nov. and Weissella thailandensis sp. nov., respectively, on the basis of phylogenetic analysis of the 165 rRNA gene sequences, DNA relatedness and phenotypic characteristics.

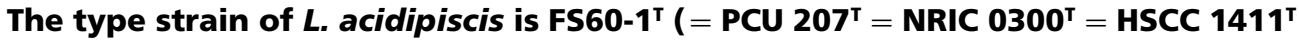
$=$ JCM $10692^{\top}=$ TISTR $1386^{\top}$ ) and the type strain of Weissella thailandensis is

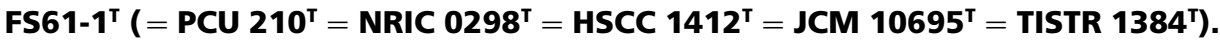

Keywords: Lactobacillus acidipiscis, Weissella thailandensis, fermented fish, lactic acid bacteria

\section{INTRODUCTION}

Lactic acid bacteria are widely distributed in Thailand in foods such as fermented fish (pla-ra, pla-paengdaeng, pla-chao, pla-chom, pla-som, etc.) and shrimp (kung-chom), fermented pork (nham), fermented vegetables (phak-gard-dong, phak-koom-dong, thuangok-dong, hom-dong, etc.), tea leaves (miang), sweetened rice (khaomak), etc. (Tanasupawat \& Komagata, 1995). These fermented foods are used for main- and side dishes, condiments, desserts and so on. The lactic acid bacteria are responsible for the souring and ripening of these foods. Some of these foods contain a high concentration of salt (pla-ra and pla-chom). Lactobacillus, Leuconostoc, Pediococcus, Enterococcus and Staphylococcus strains have been isolated from the above-mentioned foods so far (Tanasupawat \& Komagata, 1995; Tanasupawat et al., 1998).

In a previous paper, Tanasupawat et al. (1998) reported the isolation of L-lactic-acid-producing rodshaped and D-lactic-acid-producing sphere-shaped lactic acid bacteria from fermented fish (pla-ra and

The DDBJ accession numbers for the $16 \mathrm{~S}$ rRNA gene sequences reported in this paper are AB023836 (Lactobacillus acidipiscis $\mathrm{F} 60-1^{\mathrm{T}}$ ), AB023837 (Lactobacillus acidipiscis FS111), AB023838 (Weissella thailandensis FS61. $1^{\top}$ ) and AB023839 (Weissella thailandensis FS45-1). pla-chom) in Thailand. These bacteria were tentatively identified as Lactobacillus sp. (group III) and Leuconostoc species (group IV), respectively. On the basis of phylogenetic analysis of 16S rRNA gene sequences and DNA relatedness, these strains were included in the genera Lactobacillus and Weissella, respectively, and identified as new species. Lactobacillus acidipiscis sp. nov. is proposed for group III and Weissella thailandensis sp. nov. is proposed for group IV. This paper deals with the descriptions of the above species. The type strain of L. acidipiscis is FS60- $1^{\mathrm{T}}(=\mathrm{PCU}$ $207^{\mathrm{T}}=$ NRIC $0300^{\mathrm{T}}=$ HSCC $1411^{\mathrm{T}}=\mathrm{JCM} 10692^{\mathrm{T}}$ $=$ TISTR $1386^{\mathrm{T}}$ ) and the type strain of $W$. thailandensis is FS61- ${ }^{\mathrm{T}}\left(=\mathrm{PCU} 210^{\mathrm{T}}=\mathrm{NRIC} 0298^{\mathrm{T}}=\right.$ $\left.\operatorname{HSCC} 1412^{\mathrm{T}}=\mathrm{JCM} 10695^{\mathrm{T}}=\operatorname{TISTR} 1384^{\mathrm{T}}\right)$.

\section{METHODS}

Bacterial strains and growth media. Eleven strains of group III (rod-shaped) and five strains of group IV (sphere-shaped) were subjected to this study (Tanasupawat et al., 1998). The strain designations and isolation sources are shown in Tables 1 and 3. MRSH medium (a half-strength version of MRS medium; De Man et al., 1960) and GYPB medium (Tanasupawat et al., 1998) were used throughout the study.

Phenotypic and chemotaxonomic characterization. The phenotypic characteristics, the isomers of lactic acid produced, the cellular fatty acids and the DNA base com- 


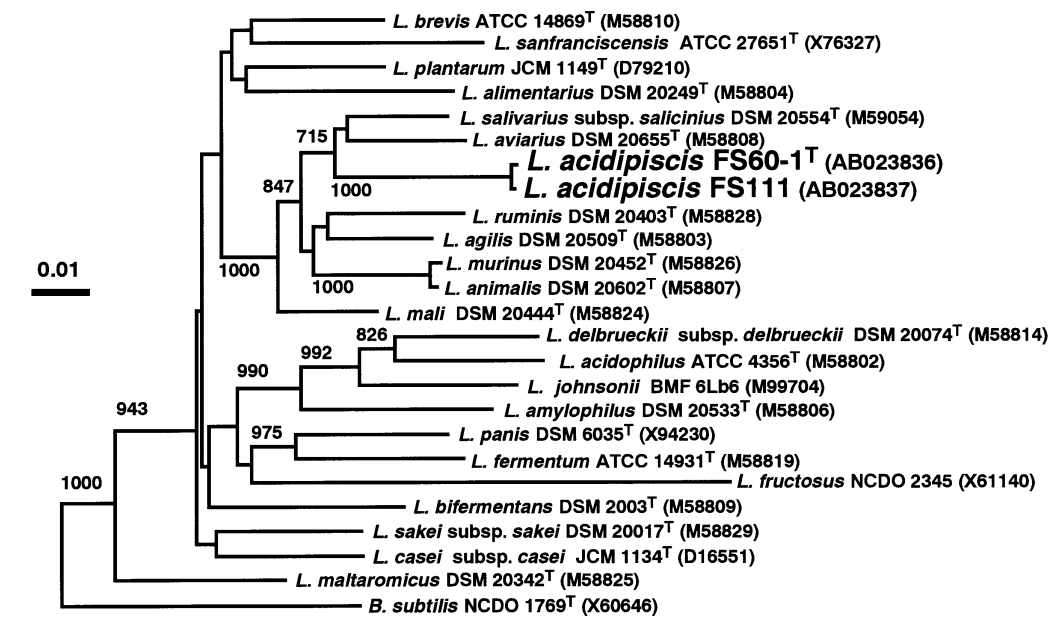

\begin{abstract}
Fig. 1. Phylogenetic relationships between Lactobacillus acidipiscis FS60-1T, FS111 and Lactobacillus species on the basis of $16 \mathrm{~S}$ rRNA gene sequences. The branching pattern was generated by the neighbourjoining method. The numbers indicate bootstrap values $>700$. Bar, 0.01 nucleotide substitutions per site.
\end{abstract}

position were all from a previous paper (Tanasupawat et al., 1998) and additional tests were carried out in this study. Cell morphologies were examined by using scanning electron microscopy.

Cell wall peptidoglycan type. The composition of cell walls was determined using the method of Komagata \& Suzuki (1987).

DNA relatedness. DNA relatedness was determined by using the fluorometric method, as described by Tanasupawat et al. (1998), and by using the colorimetric method, as described by Verlander (1992). The substrate, 3,3',5,5'-tetramethylbenzidine $/ \mathrm{H}_{2} \mathrm{O}_{2}$ solution and streptavidin-peroxidase conjugate (Boehringer Mannheim) were used for the colorimetric method. The enzyme reaction was stopped with $2 \mathrm{M}$ $\mathrm{H}_{2} \mathrm{SO}_{4}$ and the absorbance was measured at $450 \mathrm{~nm}$ with a Microplate Reader (model 3550; Bio-Rad). DNA relatedness was determined for Lactobacillus species by using the fluorometric method and for Weissella species by using the colorimetric method.

Sequencing of 16S rRNA gene. Cloning and sequencing of $16 \mathrm{~S}$ rRNA genes were carried out as described by Shida et al. (1997). Oligonucleotides 5'-AGTTTGATCCTGGCTCAG$3^{\prime}$ (primer 27FC; $5^{\prime}$ end of the $16 \mathrm{~S}$ rRNA gene) and $5^{\prime}-$ GTTACCTTGTTACGACTTC-3' (primer 1490RC; 3' end of the $16 \mathrm{~S}$ rRNA gene) were used as primers for the amplification of 16S rRNA gene by the PCR. Amplified 16S rRNA gene fragments were purified with a QIA quick Spin PCR purification kit (Qiagen) and used for sequencing templates. Sequencing was carried out by the method described by Sanger et al. (1977). A Dye Terminator Cyclesequencing FS Ready Reaction kit (Perkin-Elmer) and a model ABI 373A automatic DNA sequencer (Perkin-Elmer) were used. The seven oligonucleotides 5'-CTGCTGCCTCCCGTAG-3' (primer 341R), 5'-GTATTACCGCGGCTGCTG-3' (primer 518R), 5'-TACGGGAGGCAGCAG3' (primer 356F), 5'-GTGCCAGCAGCCGCGG-3' (primer 530F), 5'-GATTAGATACCCTGGTAG-3' (primer 803F), 5'-ACTCAAAGGAATTGACGG-3' (primer 926F) and 5'GCAACGAGCGCAACCC-3' (primer 1111F) were used as primers for sequencing of $16 \mathrm{~S}$ rRNA gene fragments.

Comparison of 16S rRNA gene sequences. Previously published 16S rRNA gene sequences were obtained from the EMBL/GenBank/DDBJ database. Multiple alignment of sequences, calculation of the nucleotide substitution rate ( $K_{\text {nuc }}$; Kimura, 1980), construction of a neighbour-joining phylogenetic tree (Saito \& Nei, 1987) and 1000-replicate bootstrap analysis for evaluation of phylogenetic tree topology (Felsenstein, 1985) were carried out with the CLUSTAL W version 1.6 program (Thompson et al., 1994). Alignment gaps and unidentified base positions were not taken into account. Accession numbers for the nucleotide sequences used for the phylogenetic analysis are shown in Figs 1 and 2.

\section{RESULTS AND DISCUSSION}

\section{S rRNA sequences}

Nucleotide sequences (1417 nucleotides) of 16S rRNA genes were determined for strain F60-1 ${ }^{\mathrm{T}}, \mathrm{FS} 61-1^{\mathrm{T}}$ and FS45-1, isolated in Thailand from the popular fermented fish pla-ra, and for strain FS111, isolated from pla-chom. These strains were studied in detail. Phylogenetic trees are shown in Figs 1 and 2.

\section{Phenotypic and chemotaxonomic characterization}

The phenotypic characteristics, the isomers of lactic acid produced, the cellular fatty acids and the DNA base composition were cited from a previous paper (Tanasupawat et al., 1998) and are mentioned in the descriptions. The cell morphologies of FS60-1 ${ }^{\mathrm{T}}$ and FS61-1 ${ }^{\mathrm{T}}$ are shown in Fig. 3.

\section{Characteristics of Lactobacillus acidipiscis sp. nov.}

L. acidipiscis strains FS60-1 ${ }^{\mathrm{T}}$ and FS111 were included in a monophyletic cluster containing Lactobacillus salivarius subsp. salicinius, Lactobacillus aviarius, Lactobacillus ruminis, Lactobacillus agilis, Lactobacillus murinus, Lactobacillus animalis and Lactobacillus mali on the basis of 16S rRNA gene sequence analysis as shown in Fig. 1. FS60- $1^{\mathrm{T}}$ and FS111 were placed in a robust (1000 counts of bootstrap values) monophyletic cluster consisting of the Lactobacillus species. The similarity values of the sequence were $99.8 \%$ between FS60- $1^{\mathrm{T}}$ and FS111, and the values were higher than $93.0 \%$ between each of these strains and each of the above seven Lactobacillus species. The 


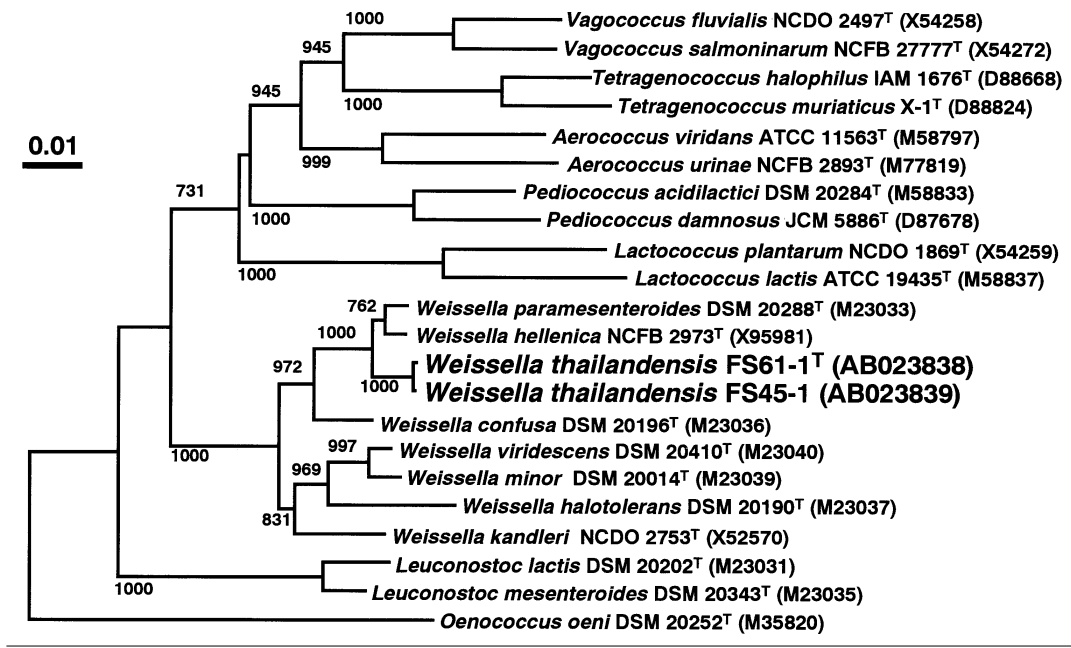

Fig. 2. Phylogenetic relationships between Weissella thailandensis FS61-1' ${ }^{\top}$ FS45-1, Weissella species and related bacteria on the basis of 16S rRNA gene sequences. The branching pattern was generated by the neighbour-joining method. The numbers indicate bootstrap values $>700$. Bar, 0.01 nucleotide substitutions per site.
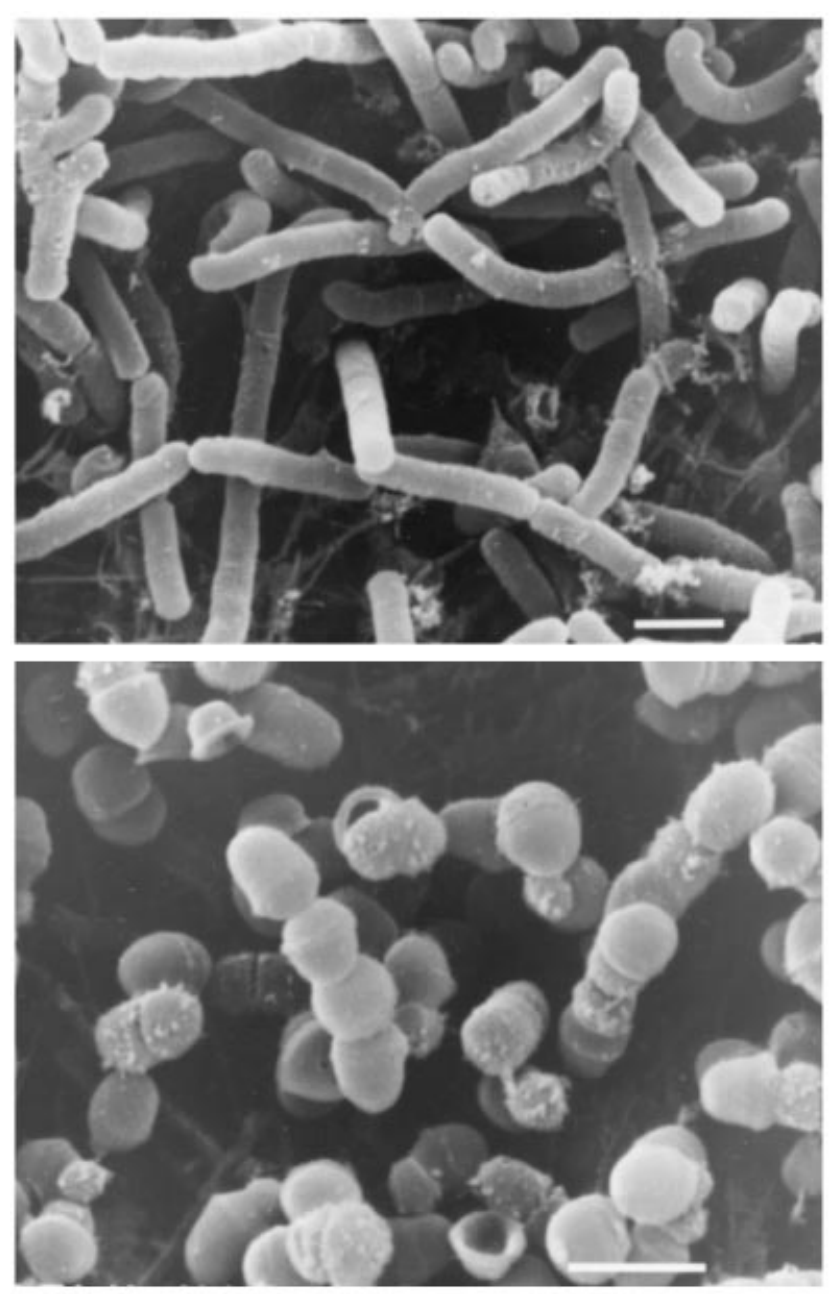

Fig. 3. Scanning electron micrographs of (top) Lactobacillus acidipiscis $\mathrm{FS60}-1^{\top}$ and (bottom) Weissella thailandensis $\mathrm{FS61-1}{ }^{\top}$. Cells were grown in MRSH broth. Bar, $1 \mu \mathrm{m}$.

similarity values were lower than $91 \cdot 3 \%$ between each of FS60- $1^{\mathrm{T}}$ and FS111 and the other Lactobacillus species (data not shown). FS111 contained L-Lys-D-
Asp in the cell wall. Values for the DNA-DNA relatedness of FS60-1 $1^{\mathrm{T}}$ and FS111 to other strains and related species are shown in Table 1 . The level of DNA-DNA relatedness clearly supported the separation of the isolates from other L-lactic-acid-producing Lactobacillus species. L. acidipiscis was differentiated from other L-lactic-acid-producing Lactobacillus species on the basis of the descriptions reported so far (Kandler \& Weiss, 1986; Hammes et al., 1992). L. acidipiscis strains grew in $10 \% \mathrm{NaCl}$ and seemed to be close to Lactobacillus farciminis but they differed in arginine hydrolysis, growth at $15^{\circ} \mathrm{C}$, acid production from D-maltose, D-mannitol and D-ribose, DNA base composition and cellular fatty acid profile (Tanasupawat et al., 1998). Characteristics differentiating L. acidipiscis from other Lactobacillus species in the same phylogenetic cluster are shown in Table 2. Recently, the starch-hydrolyser Lactobacillus manihotivorans was described, but this species clearly differs from $L$. acidipiscis by the hydrolysis of starch and a high $(48.4 \mathrm{~mol} \%) \mathrm{G}+\mathrm{C}$ content (Morlon-Guyot et al., 1998).

\section{Description of Lactobacillus acidipiscis sp. nov.}

Lactobacillus acidipiscis (a.ci.di'pis.cis. L. adj. acidus sour; L. n. piscis fish; L. adj. acidipiscis pertaining to sour fish, an isolation source of strains of this species). Cells are Gram-positive rods $(0 \cdot 4-0.6 \times 1 \cdot 2-5 \cdot 0 \mu \mathrm{m})$, non-motile, non-sporing and occur singly, in pairs and in chains. Colonies on MRSH agar plate are circular, slightly convex with an entire margin and unpigmented. Microaerophilic. Utilizes D-glucose homofermentatively and does not produce gas from glucose. Produces L-lactic acid from glucose $(>91 \%)$. Negative for catalase activity, nitrate reduction, hydrolysis of arginine, aesculin, gelatin and starch and for the formation of slime from sucrose. Most strains show no reaction in litmus milk. Grows at $25-37^{\circ} \mathrm{C}$ but not at 15 or $42{ }^{\circ} \mathrm{C}$. Does not grow at $\mathrm{pH} 4.0$ or $\mathrm{pH} 8.5$. Grows in $10 \% \mathrm{NaCl}$. Some strains grow in $12 \% \mathrm{NaCl}$. Produces acid from D-fructose, D-galactose, D-glucose and D-mannose but does not produce acid from 
Table 1. Strain designations, isolation sources, DNA base composition and DNA relatedness of Lactobacillus species

Abbreviations: NRIC, Culture Collection Center, Tokyo University of Agriculture, Tokyo, Japan; PCU, Department of Microbiology, Faculty of Pharmaceutical Sciences, Chulalongkorn University, Bangkok, Thailand; HSCC, Culture Collection of the Research and Development Department, Higeta Shoyu, Co., Ltd, Choshi, Japan; JCM, Japan Collection of Microorganisms, The Institute of Physical and Chemical Research (RIKEN), Wako, Saitama, Japan; TISTR, Thailand Institute of Scientific and Technological Research, Bangkok, Thailand. T, Type strain.

\begin{tabular}{|c|c|c|c|c|c|c|c|c|c|c|}
\hline \multirow[t]{2}{*}{ Strain } & \multicolumn{5}{|c|}{ Culture collection } & \multirow{2}{*}{$\begin{array}{c}\text { Source } \\
\text { (fermented } \\
\text { fish) }\end{array}$} & \multirow{2}{*}{$\begin{array}{c}\mathrm{G}+\mathrm{G} \\
\text { content } \\
(\mathrm{mol} \%)\end{array}$} & \multicolumn{3}{|c|}{$\begin{array}{l}\text { DNA-DNA relatedness with } \\
\text { labelled strains }(\%)\end{array}$} \\
\hline & NRIC & PCU & HSCC & JCM & TISTR & & & FS60-1 ${ }^{\mathrm{T}}$ & FS111* & FS111 \\
\hline FS60-1 ${ }^{\mathrm{T}}$ & $0300^{\mathrm{T}}$ & $207^{\mathrm{T}}$ & $1411^{\mathrm{T}}$ & $10692^{\mathrm{T}}$ & $1386^{\mathrm{T}}$ & Pla-ra & $38 \cdot 7 *$ & $100 \cdot 0$ & $94 \cdot 6$ & - \\
\hline FS109 & 0301 & 214 & & & & Pla-chom & $41 \cdot 5^{*}$ & $96 \cdot 5$ & $101 \cdot 0$ & - \\
\hline FS111 & 0302 & 208 & 1413 & 10693 & 1387 & Pla-chom & $40 \cdot 3^{*}$ & $107 \cdot 6$ & $100 \cdot 0$ & $100 \cdot 0$ \\
\hline FS4-1 & 0303 & 215 & & & & Pla-chom & $40 \cdot 3^{*}$ & 87.8 & $92 \cdot 8$ & - \\
\hline FS49-1 & 0304 & 216 & & & & Pla-ra & $40 \cdot 6^{*}$ & $106 \cdot 9$ & $99 \cdot 1$ & - \\
\hline FS53-2 & 0305 & 217 & & & & Pla-ra & - & $99 \cdot 5$ & - & - \\
\hline FS53-4 & 0306 & 218 & & & & Pla-ra & $39 \cdot 5^{*}$ & 93.6 & $93 \cdot 0$ & - \\
\hline FS55-2 & 0307 & 219 & & & & Pla-ra & - & $83 \cdot 2$ & - & - \\
\hline FS56-1 & 0308 & 206 & & & 1388 & Pla-ra & $39 \cdot 3 *$ & $85 \cdot 2$ & $92 \cdot 1$ & - \\
\hline FS58-1 & 0309 & 220 & & & & Pla-ra & $38 \cdot 6^{*}$ & 77.5 & $92 \cdot 9$ & - \\
\hline FS62-1 & 0310 & 221 & & & & Pla-ra & $38 \cdot 7 *$ & 78.9 & $95 \cdot 7$ & - \\
\hline L. agilis & $1642^{\mathrm{T}}$ & & & & & & $43 \cdot 4 \dagger$ & $4 \cdot 9$ & - & $6 \cdot 7$ \\
\hline L. animalis & & & & $5670^{\mathrm{T}}$ & $1115^{\mathrm{T}}$ & & 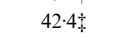 & $22 \cdot 5$ & $26 \cdot 7$ & - \\
\hline L. aviarius subsp. araffinosus & $1774^{\mathrm{T}}$ & & & $5667^{\mathrm{T}}$ & & & $41 \cdot 3 \ddagger$ & 3.6 & - & $3 \cdot 8$ \\
\hline L. farciminis & & & & $1097^{\mathrm{T}}$ & $1113^{\mathrm{T}}$ & & $36.0 \ddagger$ & $8 \cdot 3$ & $15 \cdot 7$ & - \\
\hline L. mali & $1692^{\mathrm{T}}$ & & & $1116^{\mathrm{T}}$ & & & $37 \cdot 6 \dagger$ & $3 \cdot 6$ & - & $4 \cdot 3$ \\
\hline L. murinus & & & & $1717^{\mathrm{T}}$ & $1111^{\mathrm{T}}$ & & - & $3 \cdot 6$ & - & $3 \cdot 8$ \\
\hline L. ruminis & $1689^{\mathrm{T}}$ & & & $1152^{\mathrm{T}}$ & & & $45 \cdot 5 \dagger$ & $3 \cdot 6$ & - & $4 \cdot 3$ \\
\hline L. salivarius subsp. salicinius & $1072^{\mathrm{T}}$ & & & $1150^{\mathrm{T}}$ & & & $28 \cdot 5 \S, 36 \cdot 6 \%$ & - & - & - \\
\hline L. salivarius subsp. salivarius & & & & $1231^{\mathrm{T}}$ & $1112^{\mathrm{T}}$ & & $28.3 \S$ & $11 \cdot 3$ & $27 \cdot 3$ & - \\
\hline
\end{tabular}

* Data from Tanasupawat et al. (1998).

$\dagger$ Data from Weiss et al. (1981).

t Data from Gasser \& Mandel (1968).

$\S$ Data from Entani et al. (1986).

Table 2. Characteristics that differentiate Lactobacillus acidipiscis from other L-lactic-acid-producing species

T, Type strain; ND, not determined.

\begin{tabular}{|c|c|c|c|c|c|c|c|c|c|c|}
\hline \multirow[t]{2}{*}{ Characteristic } & \multicolumn{2}{|c|}{ L. acidipiscis* } & \multirow{2}{*}{$\begin{array}{c}\text { L. agilis } \\
\text { NRIC } 1642^{\mathrm{T}}\end{array}$} & \multirow{2}{*}{$\begin{array}{l}\text { L. animalis } \\
\text { TISTR } 1115^{\mathrm{T}}\end{array}$} & \multirow{2}{*}{$\begin{array}{l}\text { L. aviarius subsp. } \\
\text { araffinosus } \\
\text { NRIC } 1774^{\mathrm{T}} \dagger\end{array}$} & \multirow{2}{*}{$\begin{array}{l}\text { L. farciminis } \\
\text { TISTR } 1113^{\mathrm{T}}\end{array}$} & \multirow{2}{*}{$\begin{array}{c}\text { L. mali } \\
\text { NRIC 1692 }^{\mathrm{T}}\end{array}$} & \multirow{2}{*}{ 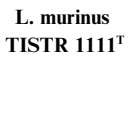 } & \multirow{2}{*}{$\begin{array}{l}\text { L. ruminis } \\
\text { NRIC } 1689^{\mathrm{T}}\end{array}$} & \multirow{2}{*}{$\begin{array}{c}\text { L. salivarius } \\
\text { subsp. } \\
\text { salicinius } \\
\text { NRIC 1072 }\end{array}$} \\
\hline & FS60-1 ${ }^{\mathrm{T}}$ & 11 strains & & & & & & & & \\
\hline Diaminopimelic acid in cell wall & - & 0 & $+\$$ & - & - & - & $+\$$ & - & $+\S$ & $-\|$ \\
\hline Arginine hydrolysis & - & 0 & - & - & ND & + & - & - & - & - \\
\hline Growth at $15^{\circ} \mathrm{C}$ & - & 0 & $-\hbar$ & - & - & + & $+\hbar$ & - & $-\S$ & $-\|$ \\
\hline Growth in $10 \% \mathrm{NaCl}$ & + & $11 \%$ & - & - & ND & + & - & - & - & - \\
\hline \multicolumn{11}{|l|}{ Acid from: } \\
\hline D-Maltose & + & 10 & + & + & + & - & - & + & + & + \\
\hline D-Mannitol & + & 2 & + & - & - & - & + & + & - & + \\
\hline Raffinose & - & 0 & + & + & - & - & - & + & + & + \\
\hline D-Ribose & + & 11 & + & - & - & - & - & - & + & + \\
\hline Sorbitol & - & 0 & - & - & - & - & + & + & - & + \\
\hline
\end{tabular}

* Data from Tanasupawat et al. (1998).

$\dagger$ Data from Fujisawa et al. (1984).

† Data from Weiss et al. (1981).

$\S$ Data from Sharpe et al. (1973).

\| Data from Entani et al. (1986).

- Number of positive strains.

cellobiose, gluconate, D-melibiose, D-melezitose, methyl $\alpha$-D-glucoside, raffinose, D-sorbitol and Dxylose. Some strains produce acid weakly from lactose and salicin. Variable reactions for D-amygdalin, L-arabinose, glycerol, maltose, D-mannitol, L-rhamnose, sucrose and D-trehalose. Requires niacin and 
Table 3. Strain designations, isolation sources, DNA base composition and DNA relatedness of Weisselia species

T, Type strain.

\begin{tabular}{|c|c|c|c|c|c|c|c|c|c|c|}
\hline \multirow[t]{3}{*}{ Species } & \multirow[t]{3}{*}{ Strain } & \multicolumn{5}{|c|}{ Culture collection } & \multirow{3}{*}{$\begin{array}{c}\text { Source } \\
\text { (fermented } \\
\text { fish) }\end{array}$} & \multirow{3}{*}{$\begin{array}{c}G+C \text { content } \\
(\mathrm{mol} \%)\end{array}$} & \multirow{2}{*}{\multicolumn{2}{|c|}{$\begin{array}{c}\text { DNA-DNA } \\
\text { relatedness with } \\
\text { labelled strains }(\%)\end{array}$}} \\
\hline & & \multirow[t]{2}{*}{ NRIC } & \multirow[t]{2}{*}{ JCM } & \multirow[t]{2}{*}{$\mathbf{P C U}$} & \multirow[t]{2}{*}{ HSCC } & \multirow[t]{2}{*}{ TISTR } & & & & \\
\hline & & & & & & & & & FS45 & FS61-1 $^{\mathrm{T}}$ \\
\hline$W$. thailandensis & $\mathrm{FS} 61-1^{\mathrm{T}}$ & $0298^{\mathrm{T}}$ & $10695^{\mathrm{T}}$ & $210^{\mathrm{T}}$ & $1412^{\mathrm{T}}$ & $1384^{\mathrm{T}}$ & Pla-ra & $41 \cdot 2 *$ & $96 \cdot 9$ & $100 \cdot 0$ \\
\hline$W$. thailandensis & FS45 & 0295 & & 211 & & & Pla-ra & $40 \cdot 0 *$ & $100 \cdot 0$ & $97 \cdot 9$ \\
\hline W. thailandensis & FS45-1 & 0296 & 10694 & 209 & 1410 & 1385 & Pla-ra & $38 \cdot 0^{*}$ & $92 \cdot 1$ & $95 \cdot 5$ \\
\hline$W$. thailandensis & FS46-2 & 0297 & & 212 & & & Pla-ra & $39 \cdot 8^{*}$ & $104 \cdot 6$ & $102 \cdot 5$ \\
\hline$W$. thailandensis & FS61-2 & 0299 & & 213 & & & Pla-ra & & $84 \cdot 6$ & $106 \cdot 1$ \\
\hline$W$. paramesenteroides & & $1542^{\mathrm{T}}$ & $9890^{\mathrm{T}}$ & & & & & $40 \cdot 4 \dagger$ & $36 \cdot 0$ & $21 \cdot 5$ \\
\hline$W$. hellenica & & $0203^{\mathrm{T}}$ & $10103^{\mathrm{T}}$ & & & & & $39 \cdot 4 \hbar$ & $28 \cdot 2$ & $19 \cdot 3$ \\
\hline$W$. confusa & & $0207^{\mathrm{T}}$ & $1093^{\mathrm{T}}$ & & & & & $47 \cdot 0 \dagger$ & $15 \cdot 7$ & $16 \cdot 7$ \\
\hline
\end{tabular}

* Data from Tanasupawat et al. (1998).

$\dagger$ Data from Schillinger et al. (1989).

† Data from Collins et al. (1993).

Table 4. Characteristics that differentiate Weisselia thailandensis from related species

T, Type strain.

\begin{tabular}{|c|c|c|c|c|c|c|}
\hline \multirow[t]{2}{*}{ Characteristic } & \multicolumn{2}{|c|}{ W. thailandensis* } & \multirow{2}{*}{$\begin{array}{l}W . \text { confusa } \\
\text { NRIC } 0207^{\mathrm{T}}\end{array}$} & \multirow{2}{*}{$\begin{array}{l}W . \text { hellenica } \\
\text { NRIC } 0203^{T}\end{array}$} & \multirow{2}{*}{$\begin{array}{c}W \cdot \text { paramesenteroides } \\
\text { NRIC } 1542^{\mathrm{T}}\end{array}$} & \multirow{2}{*}{$\begin{array}{l}\text { Leuconostoc } \\
\text { mesenteroides } \\
\text { NRIC } 1541^{\mathrm{T}}\end{array}$} \\
\hline & FS61-1 ${ }^{\mathrm{T}}$ & 5 strains & & & & \\
\hline $\mathrm{NH}_{3}$ from arginine & - & 0 & + & - & - & - \\
\hline Slime from sucrose & - & 0 & + & - & - & + \\
\hline Growth in $10 \% \mathrm{NaCl}$ & + & $5 \ddagger$ & - & - & - & $-\S$ \\
\hline \multicolumn{7}{|l|}{ Acid from: } \\
\hline L-Arabinose & + & 5 & - & + & + & + \\
\hline Cellobiose & - & 0 & + & + & - & + \\
\hline D-Galactose & + & 5 & - & + & + & + \\
\hline Lactose & - & 3 & - & - & - & + \\
\hline D-Mannitol & - & 0 & - & - & - & + \\
\hline D-Melibiose & + & 5 & - & - & + & + \\
\hline Raffinose & + & 5 & - & - & - & + \\
\hline D-Ribose & + & 5 & - & + & + & - \\
\hline Salicin & - & 0 & - & + & - & + \\
\hline Sucrose & + & 4 & + & - & + & + \\
\hline D-Trehalose & + & 4 & + & - & + & + \\
\hline D-Xylose & - & 0 & - & + & - & + \\
\hline
\end{tabular}

* Data from Tanasupawat et al. (1998).

$\dagger$ Data from Takahashi et al. (1992).

$\S$ Data from this study.

$\ddagger$ Number of positive strains.

calcium pantothenate for growth. Major cellular fatty acids are straight-chained $\mathrm{C}_{16: 0}$ and $\mathrm{C}_{18: 1}$. L-Lys-DAsp in the cell wall. The $\mathrm{G}+\mathrm{C}$ content of the DNA ranges from 38.6 to $41.5 \mathrm{~mol} \%$. Isolated from fer- mented fish (pla-ra and pla-chom) in Thailand. The type strain is FS60- $1^{\mathrm{T}}\left(=\mathrm{PCU} 207^{\mathrm{T}}=\mathrm{NRIC} 0300^{\mathrm{T}}=\right.$ HSCC $1411^{\mathrm{T}}=\mathrm{JCM} 10692^{\mathrm{T}}=$ TISTR $\left.1386^{\mathrm{T}}\right)$. The type strain has the characteristics given in the descrip- 
tion of species and in Tables 1 and 2. The $\mathrm{G}+\mathrm{C}$ content of the type strain is $38.7 \mathrm{~mol} \%$.

\section{Characteristics of Weissella thailandensis sp. nov.}

Weissella thailandensis strains $\mathrm{FS} 61-1^{\mathrm{T}}$ and FS45-1 were included in a monophyletic cluster containing Weissella species on the basis of 16S rRNA gene sequence analysis, as shown in Fig. 2. FS61- $1^{\mathrm{T}}$ and FS45-1 were placed in a robust (1000 counts of bootstrap values) monophyletic cluster consisting of the Weissella species. The similarity values of the sequence were $99.9 \%$ between FS61- ${ }^{\mathrm{T}}$ and FS45-1 and higher than $94.0 \%$ between FS61- $1^{\mathrm{T}}$ or FS45-1 and each of seven Weissella species. The similarity values were lower than $90 \cdot 2 \%$ between FS61-1 ${ }^{\mathrm{T}}$ or FS45-1 and each of the Leuconostoc and Lactococcus strains (data not shown). FS61- $1^{\mathrm{T}}$ contained L-Lys-L$\mathrm{Ala}_{2}$ in the cell walls. Values of DNA-DNA relatedness of FS61- $1^{\mathrm{T}}$ and FS45-1 to other strains and related species are shown in Table 3. The level of DNA-DNA relatedness clearly supported the separation of the isolates from other Weissella species. Garvie (1986) mentioned the growth of some (not all) Weissella (Leuconostoc) paramesenteroides strains in 3 and $6.5 \%$ $\mathrm{NaCl}$. In contrast, all $W$. thailandensis strains tested grew in $10 \% \mathrm{NaCl}$. This is regarded as a characteristic of the species. Characteristics differentiating $W$. thailandensis from other Weissella species in the same phylogenetic cluster are shown in Table 4 . The $W$. thailandensis strains produced D-lactic acid along with other Weissella species (Tsakalidou et al., 1997).

\section{Description of Weissella thailandensis sp. nov.}

Weissella thailandensis (thai.lan'den.sis. M.L. fem. adj. thailandensis pertaining to Thailand, where the strains were first isolated).

Cells are Gram-positive cocci $(0.5-0.7 \mu \mathrm{m})$, nonmotile, non-sporing and occur in pairs or in chains. Colonies on MRSH agar plates are usually opaque, circular, slightly convex with an entire margin and unpigmented. Microaerophilic. Utilizes D-glucose heterofermentatively and produces gas from glucose. Produces D-lactic acid from glucose $(>92 \%)$. Negative for catalase activity, nitrate reduction, hydrolysis of arginine, aesculin, gelatin and starch, for the formation of slime from sucrose and for the reaction in litmus milk. Final pH in MRSH medium is $\mathrm{pH} 4 \cdot 3-4 \cdot 6$. Grows at $25-37{ }^{\circ} \mathrm{C}$ but not at $42{ }^{\circ} \mathrm{C}$. Grows at $\mathrm{pH} 8 \cdot 0$ but not at $\mathrm{pH} 4.5$ or $\mathrm{pH} 8.5$. Grows in $10 \% \mathrm{NaCl}$. Produces acid from D-ribose, L-arabinose, D-fructose, D-galactose, D-glucose, D-mannose, maltose, D-melibiose, raffinose and L-rhamnose but does not produce acid from D-amygdalin, D-cellobiose, glycerol, Dmannitol, D-melezitose, salicin, D-sorbitol or D-xylose. Requires niacin and calcium pantothenate for growth. In addition, some strains require thiamine or riboflavin. Major cellular fatty acids are straight-chained $\mathrm{C}_{16: 0}$ and $\mathrm{C}_{20: 1}$. L-Lys-L-Ala ${ }_{2}$ in the cell wall. The $\mathrm{G}+\mathrm{C}$ content of the DNA ranges from 38.0 to
$41 \cdot 2 \mathrm{~mol} \%$. Isolated from fermented fish (pla-ra) in Thailand. The type strain is FS61-1 ${ }^{\mathrm{T}}\left(\mathrm{PCU} 210^{\mathrm{T}}=\right.$ NRIC $0298^{\mathrm{T}}=\mathrm{HSCC} 1412^{\mathrm{T}}=\mathrm{JCM} 10695^{\mathrm{T}}=$ TISTR $1384^{\mathrm{T}}$ ). The type strain has the characteristics given in the description of species and in Tables 3 and 4. The $\mathrm{G}+\mathrm{C}$ content of the type strain is $41.2 \mathrm{~mol} \%$.

\section{ACKNOWLEDGEMENTS}

We thank T. Yoshida and T. Seki (International Center of Cooperative Research in Biotechnology, Osaka University, Japan) for their encouragement and support during this study and Ken-ichiro Suzuki (Japan Collection of Microorganisms) for analysing the cell walls.

\section{REFERENCES}

Collins, M. D., Samelis, J., Metaxopoulos, J. \& Wallbanks, S. (1993). Taxonomic studies on some leuconostoc-like organisms from fermented sausage: description of a new genus Weissella for the Leuconostoc paramesenteroides group of species. J Appl Bacteriol 75, 595-603.

De Man, J. C., Rogosa, M. \& Sharpe, M. E. (1960). A medium for the cultivation of lactobacilli. J Appl Bacteriol 23, 130-135.

Entani, E., Masai, H. \& Suzuki, K. (1986). Lactobacillus acetotolerans, a new species from fermented vinegar broth. Int J Syst Bacteriol 36, 544-549.

Felsenstein, J. (1985). Confidence limits on phylogenies: an approach using the bootstrap. Evolution 39, 783-791.

Fujisawa, T., Shirasaka, S., Watabe, J. \& Mitusoka, T. (1984). Lactobacillus aviarius sp. nov.: a new species isolated from the intestine of chickens. Syst Appl Microbiol 5, 414-420.

Garvie, E. I. (1986). Genus Leuconostoc van Tieghem 1878. In Bergey's Manual of Systematic Bacteriology, vol. 2, pp. 1071-1075. Edited by P. H. A. Sneath, N. S. Mair, M. E. Sharpe \& J. G. Holt. Baltimore: Williams \& Wilkins.

Gasser, F. \& Mandel, M. (1968). Deoxyribonucleic acid base composition of the genus Lactobacillus. J Bacteriol 96, 580-588.

Hammes, W. P., Weiss, N. \& Holzapfel, W. (1992). The genera Lactobacillus and Carnobacterium. In The Prokaryotes, vol. II, pp. 1536-1594. Edited by A. Balows, H. G. Trüper, M. Dworkin, W. Harder \& K.-H. Schleifer. New York: Springer.

Kandler, O. \& Weiss, N. (1986). Genus Lactobacillus Beijerinck 1901, 212. In Bergey's Manual of Systematic Bacteriology, vol. 2, pp. 1209-1234. Edited by P. H. A. Sneath, N. S. Mair, M. E. Sharpe \& J. G. Holt. Baltimore: Williams \& Wilkins.

Kimura, M. (1980). A simple method for estimating evolutionary rates of base substitutions through comparative studies of nucleotide sequences. J Mol Evol 16, 111-120.

Komagata, K. \& Suzuki, K. (1987). Lipid and cell wall analysis in bacterial systematics. Methods Microbiol 19, 161-207.

Morlon-Guyot, J., Guyot, J. P., Pot, B., Jacob de Haut, I. \& Raimbault, M. (1998). Lactobacillus manihotivorans sp. nov., a new starch-hydrolysing lactic acid bacterium isolated during cassava sour starch fermentation. Int $J$ Syst Bacteriol 48, 1101-1109.

Saito, N. \& Nei, M. (1987). A neighbor-joining method: a new method for reconstructing phylogenetic trees. Mol Biol Evol 44, 406-425.

Sanger, F., Nicklen, S. \& Coulson, A. R. (1977). DNA sequencing with chain-terminating inhibitors. Proc Natl Acad Sci USA 74, $5464-5467$. 
Schillinger, U., Holzapfel, W. \& Kandler, O. (1989). Nucleic acid hybridization studies of Leuconostoc and heterofermentative lactobacilli and description of Leuconostoc amelibiosum. Syst Appl Microbiol 12, 48-55.

Sharpe, M. E., Latham, M. J., Garvie, E. I., Zirngibl, J. \& Kandler, O. (1973). Two new species of Lactobacillus isolated from the bovine rumen, Lactobacillus ruminis sp. nov. and Lactobacillus vitulinus sp. nov. J Gen Microbiol 77, 37-49.

Shida, O., Takagi, H., Kadowaki, K., Nakamura, L. K. \& Komagata, K. (1997). Transfer of Bacillus alginolyticus, Bacillus chondoroitinus, Bacillus curdlanolyticus, Bacillus glucanolyticus, Bacillus kobensis and Bacillus thiaminolyticus to the genus Paenibacillus and emended description of the genus Paenibacillus. Int J Syst Bacteriol 47, 289-298.

Takahashi, M., Okada, S., Uchimura, T. \& Kozaki, M. (1992). Leuconostoc amelibiosum Schillinger, Holzapfel, and Kandler 1989 is a later subjective synonym of Leuconostoc citreum Farrow, Facklam, and Collins. Int J Syst Bacteriol 42, 649-651.

Tanasupawat, S. \& Komagata, K. (1995). Lactic acid bacteria in fermented foods in Thailand. World J Microbiol Biotechnol 11, $253-256$.
Tanasupawat, S., Okada, S. \& Komagata, K. (1998). Lactic acid bacteria found in fermented fish in Thailand. J Gen Appl Microbiol 44, 193-200.

Thompson, J. D., Higgins, D. G. \& Gibson, T. J. (1994). CLUSTAL W: improving the sensitivity of progressive multiple sequence alignment through sequence weighting, position-specific gap penalties and weight matrix choice. Nucleic Acids Res 22, 4673-4680.

Tsakalidou, E., Samelis, J., Metaxopoulos, J. \& Kalanatzopoulos, G. (1997). Atypical Leuconostoc-like Weissella strains isolated from meat, sharing low phenotypic relatedness with the so far recognized arginine-negative Weissella $\mathrm{spp}$. as revealed by SDSPAGE of whole cell proteins. Syst Appl Microbiol 20, 659-664.

Verlander, C. P. (1992). Detection of horseradish peroxidase by colorimetry. In Nonisotopic DNA Probe Techniques, pp. 185-201. Edited by L. J. Kricka. New York: Academic Press.

Weiss, N., Schillinger, U., Laternser, M. \& Kandler, O. (1981). Lactobacillus sharpeae sp. nov. and Lactobacillus agilis sp. nov., two new species of homofermentative, meso-diaminopimelic acid-containing lactobacilli isolated from sewage. Zentbl Bakteriol Hyg 1 Abt Orig C 2, 242-253. 